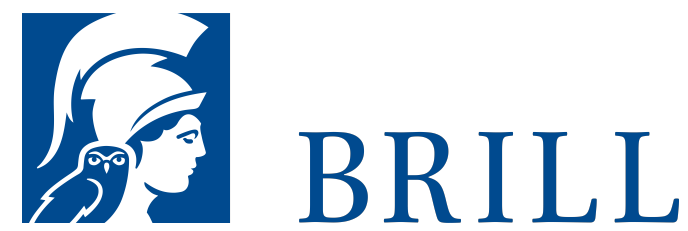

\title{
50 Jahre Wilhelm Fink Verlag
}

\section{Eine Chronik}

Authors: Henning Siekmann and Henning Siekmann

$5^{\circ}$ Jahre Wilhelm Fink Verlag. Eine Chronik Als â€žKreativpool der Geisteswissenschaftenâ€ $\square$ w ̃̃ $1 / 4$ rdigte die SÃ $1 / 4$ ddeutsche Zeitung den Wilhelm Fink Verlag, der 1962 vom Verleger gleichen Namens in MÃ $1 / 4$ nchen gegrã $1 / 4$ ndet wurde und zunÃachst weitgehend auf literaturwissenschaftliche und philosophische Literatur spezialisiert war. SpÃăter rã $1 / 4$ ckten Bild- und Medienwissenschaften, Kulturgeschichte und Philosophie immer mehr in den Mittelpunkt. Neben dem Fachbuch wird auch das wissenschaftliche Sachbuch fã $1 / 4 \mathrm{r}$ ein breiteres, anspruchsvolles Lesepublikum im Programm ausgebaut. Dabei versteht sich der Wilhelm Fink Verlag als Impulsgeber f̂̃ $1 / 4$ r aktuelle Themen und Debatten. In der Tat bestimmen die Autoren des Wilhelm Fink Verlages maÃ Ÿgeblich die Diskussion, wenn Themen und Namen aus den Bereichen der Bild- und Medienwissenschaften, der Kulturgeschichte, der Literaturwissenschaft und der Philosophie in den groÃŸen Feuilletons im Mittelpunkt stehen.

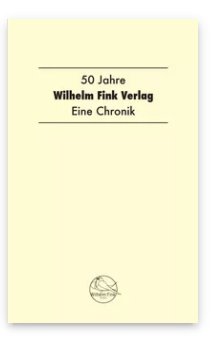

Pages: 56 Seiten, $45 \mathrm{~s} / \mathrm{w}$ und 1 farb. Abb.

Language:

German

Subjects:

Cultural History,

Literature and

Cultural Studies

Publisher: Brill |

Fink

E-Book (PDF)

Released online:

26 Nov 2019

ISBN: 978-3-

8467-0015-0

Paperback

Publication date:

21 May 2012

ISBN: 978-3-

7705-5414-O

List price

Open Access 
For more information see brill.com

Order information: Order online at brill.com +44330 333 0049 | customerservices@brill.com Submission information: brill.com/authors

Titles published by Brill | Fink, Brill | mentis or Brill | Schöningh: +49(o)715413279216| brill@brocom.de 